RESIDENT

\& FELLOW

SECTION

Section Editor

Mitchell S.V. Elkind,

MD, MS

A. Abrahão, MD

C.C.H. de Aquino, MD

J.L. Pedroso, MD

R.F. Baiense, MD

R.A. Oliveira, MD

V.M. Jorge, MD

O.G.P. Barsottini, MD, $\mathrm{PhD}$

Address correspondence and reprint requests to Dr. J.L Pedroso, Departamento de Neurologia e Neurocirurgia, Universidade Federal de São Paulo, Rua Pedro de Toledo, 650, CEP 04039-000, São Paulo, SP, Brazil

zeluizpedroso@yahoo.com.br

\section{Teaching NeuroImages: \\ Brucellosis mimicking demyelinating disease}
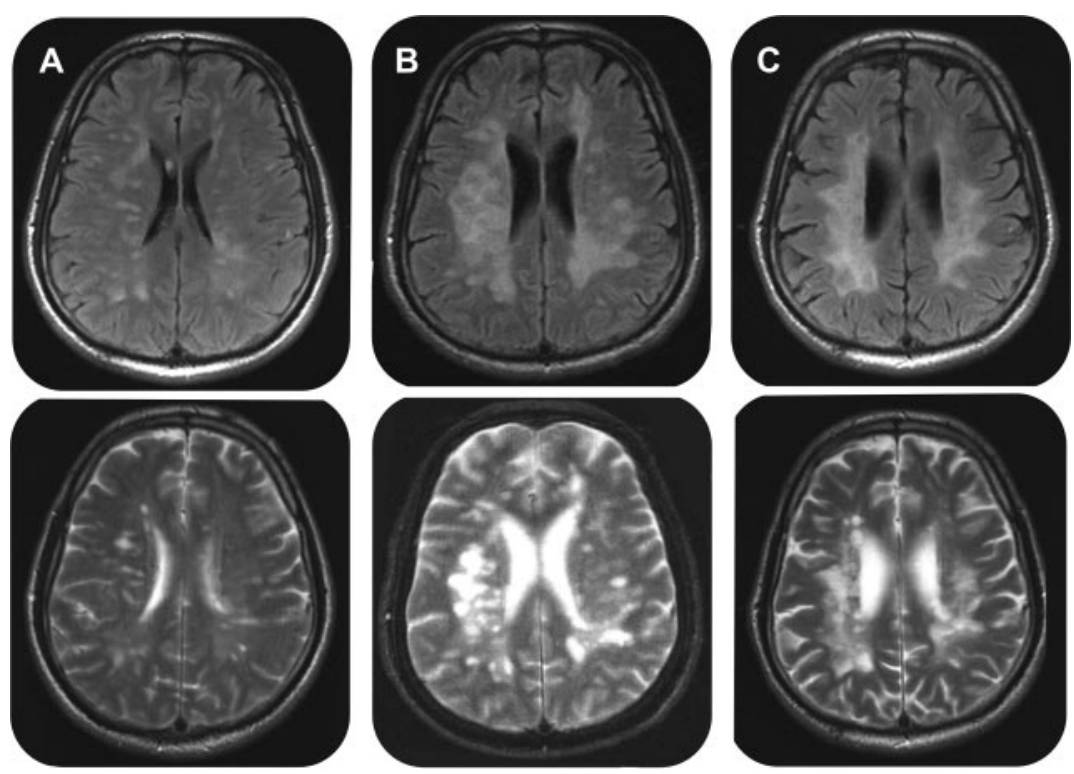

Fluid-attenuated inversion recovery (first row) and T2-weighted (second row) brain MRI (1.5 T) showed diffuse white matter hyperintensities (A), evolving to confluent lesions 1 month later (B). T1-weighted brain MRI showed no gadolinium enhancement and no corpus callosum involvement was found. (C) Follow-up imaging 1 year after treatment. These findings are atypical for demyelinating diseases, but are consistent with neurobrucellosis. ${ }^{1}$

A 57-year-old man presented with a 4-week history of fever, visual loss, and progressive ataxic gait. $\mathrm{He}$ worked as a truck driver and had been in contact with raw sheepskin a few months prior. Neurologic examination showed drowsiness, pseudobulbar syndrome, hyperreflexia, ataxia, and optic disc edema. He had a lymphocytic pleocytosis and diffuse hyperintense white matter lesions on brain MRI (figure). Serum and urine PCR were positive for Brucella spp. Rheumatologic and other serologic tests were negative. Partial improvement was achieved with doxycycline, rifampin, and trimethoprim-sulfamethoxazole.
Brain MRI suggesting demyelinating disease with atypical clinical presentation should raise other diagnostic possibilities such as nervous system infections and acute disseminated encephalomyelitis. ${ }^{1,2}$

\section{REFERENCES}

1. Al-Sous MW, Bohlega S, Al-Kawi MZ, Alwatban J, McLean DR. Neurobrucellosis: clinical and neuroimaging correlations. AJNR Am J Neuroradiol 2004;25: $395-401$.

2. Gul HC, Erdem H, Bek S. Overview of neurobrucellosis: a pooled analysis of 187 cases. Int J Infect Dis 2009;13: e339-e343. 


\section{Neurology}

Teaching NeuroImages: Brucellosis mimicking demyelinating disease

A. Abrahão, C.C.H. de Aquino, J.L. Pedroso, et al.

Neurology 2011;76; $\mathrm{e} 51$

DOI 10.1212/WNL.0b013e3182104370

\section{This information is current as of March 14, 2011}

\section{Updated Information \&} Services

References

Subspecialty Collections

Permissions \& Licensing

Reprints including high resolution figures, can be found at: http://n.neurology.org/content/76/11/e51.full

This article cites 2 articles, 0 of which you can access for free at: http://n.neurology.org/content/76/11/e51.full\#ref-list-1

This article, along with others on similar topics, appears in the following collection(s):

All Demyelinating disease (CNS)

http://n.neurology.org/cgi/collection/all_demyelinating_disease_cns All Infections

http://n.neurology.org/cgi/collection/all_infections

MRI

http://n.neurology.org/cgi/collection/mri

Information about reproducing this article in parts (figures,tables) or in its entirety can be found online at:

http://www.neurology.org/about/about_the_journal\#permissions

Information about ordering reprints can be found online:

http://n.neurology.org/subscribers/advertise

Neurology ${ }^{\circledR}$ is the official journal of the American Academy of Neurology. Published continuously since 1951, it is now a weekly with 48 issues per year. Copyright Copyright @ 2011 by AAN Enterprises, Inc.. All rights reserved. Print ISSN: 0028-3878. Online ISSN: 1526-632X.

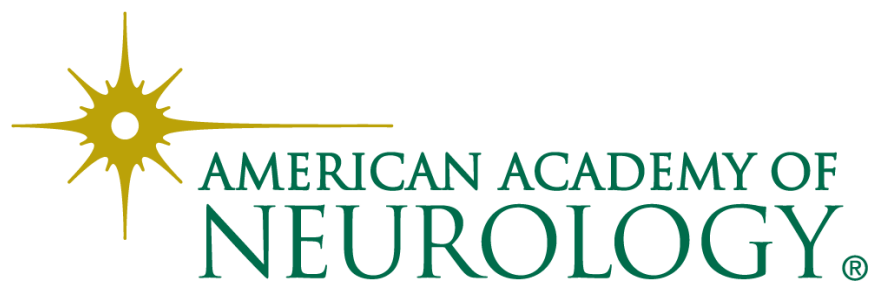

